\title{
LAWYERS AND POLICYMAKERS IN GOVERNMENT
}

\author{
PETER H. SCHUCK*
}

\section{INTRODUCTION}

If my government service holds any interest for this symposium's other participants and readers, it is because I served in a different capacity than most lawyers in government. First, neither I nor the agency that I helped to runthe Office of the Assistant Secretary for Planning and Evaluation ("ASPE")did any legal work, however broadly defined. Quite the contrary. The head of my agency, Henry Aaron, was a distinguished economist who had been (and remains) a senior fellow at the Brookings Institution. Our staff consisted of almost 100 policy analysts, mostly trained in economics and other social sciences. To my knowledge, none were lawyers.

Second, the Secretary of the Department of Health, Education, and Welfare ("DHEW"), Joseph A. Califano, Jr., held what I imagine is an unusual view of the role that lawyers can and should play in public life. Califano, a famously sophisticated, energetic, demanding, politically adroit, and wellconnected individual, seemed to believe that God in His or Her infinite wisdom had endowed lawyers with special faculties for governance, policy development, and political leadership. Lawyers were somehow better equipped than other mortals to perform the chief tasks of high-level government: politics and persuasion, analysis and synthesis, management and implementation. Califano acknowledged, of course, that policy analysts, program specialists, budgeteers, personnel experts, data gatherers, researchers, inspectors, and other government officials also possessed valuable skills. These individuals, however, were essentially technicians, functionaries, staff aides, and consultants. The most talented of them could rise above these limitations, of course, but their more

\footnotetext{
Copyright $\odot 1998$ by Law and Contemporary Problems

This essay is also available at http://www.law.duke.edu/journals/61LCPSchuck.

* Simeon E. Baldwin Professor of Law, Yale Law School and John Marshall Harlan Visiting Professor of Law, New York Law School (Spring 1998).

I am grateful to Neal Devins for creating this symposium, which provides me with an intellectually respectable excuse to reminisce about and reflect on an important (at least to me) chapter in my professional life. Twenty years ago, from April 1977 to January 1979, I served as the Principal Deputy Assistant Secretary for Planning and Evaluation in the U.S. Department of Health, Education, and Welfare ("DHEW"). Shortly thereafter, Congress divided DHEW into two separate departments: Health and Human Services, and Education.
} 
typical role should be to support the lawyers who did-and in a sensible world, should-exercise the real power.'

The most interesting aspect of my government experience for purposes of this symposium was the frequent bureaucratic competition and conflict that occurred between ASPE and the Department's lawyers. ASPE had played a preeminent role in the preceding Nixon and Ford administrations, where it had essentially dominated the Department and hence the domestic policy agendas of those presidencies. ${ }^{2}$ This powerful position inevitably brought the agency into bureaucratic and policy disputes with other ambitious departmental officials, including the lawyers.

ASPE ordinarily served as the Secretary's lead agency for the development of his major policy initiatives. Because these initiatives tended to cut across a number of programmatic and agency lines, they required central coordination of the relevant players within the Department. ${ }^{3}$ In addition, ASPE usually spearheaded the Department's efforts to obtain congressional reauthorization of many established health, education, income maintenance, social service, child welfare, and other programs. ASPE was also responsible for much of the Department's policy-oriented research and for the evaluation of the effectiveness of its existing programs. ${ }^{4}$ Finally, no significant regulatory and legislative proposal - whether developed by ASPE in the first instance or not-could go to the Secretary for his final approval until ASPE had reviewed it for its consistency with departmental policy, which further increased ASPE's leverage within the Department.

1. This idiosyncratic view bore the marks not only of Califano's own legal training and experience but of his truly remarkable background in government, which combined law, politics, and policymaking at the highest levels. An insider par excellence, Califano rivaled-indeed, in some ways dwarfed-his President, Jimmy Carter, as a political force in Washington. Entering federal service during the early 1960s as a young lawyer in the Pentagon, Califano's immense energy and talent soon carried him from the Army general counsel's office to a position as one of Defense Secretary Robert McNamara's "whiz kids" and troubleshooters. From there, Califano moved to the White House staff where he quickly rose to become President Lyndon Johnson's chief domestic policy advisor, a position from which he orchestrated what remains the largest, most rapid expansion of the administrative state since the New Deal. When he left office with Johnson in 1969, Califano established a major Washington law firm and for a time headed the Democratic Party, where he cultivated and supported a new generation of politicians at the federal, state, and local levels.

2. Many in the Department maintained that William Morrill, who headed ASPE during David Mathews' brief tenure as Secretary, essentially ran the Department. Califano, the consummate political operator and string-puller, refused to delegate such power to his subordinates and reduced ASPE's influence over departmental affairs accordingly.

3. Examples of such initiatives during my tenure at DHEW included the far-reaching proposals for welfare reform, national health insurance, child health programs, Social Security reform, long term care and deinstitutionalization, teenage pregancy prevention, and others. In addition, of course, such efforts often required coordination of and with other federal departments and consultation with state and local governments, which typically had to implement these programs and often contributed much of the funding.

4. In this capacity, ASPE directly sponsored major social experiments (such as those testing the behavioral effects of national health insurance and the negative income tax), coordinated the policy research and evaluation efforts of the program agencies, and conducted some research and evaluation in-house. 
Although Califano had no intention of giving ASPE the free rein that it had enjoyed in the previous administrations, his need for high-level policy expertise and his deep-seated suspicion of program bureaucrats ${ }^{5}$ assured that ASPE would continue to be a formidable force in departmental policymaking. As a result of his long experience at the apex of national power-he shaped policy from the Johnson White House-Califano was convinced that the career officials who ran the programs could not be trusted to accept his leadership and implement his priorities unreservedly. Instead, he assumed that they were primarily driven by narrow bureaucratic concerns, by parochial views of their programs, and by the demands of the special interests-often well-organized client and provider groups with close ties to Congress-on which the program officials traditionally relied for political support and policy advice. ${ }^{6}$ Like most other cabinet secretaries, Califano sought to solve this problem by surrounding himself with a coterie of advisors whom he felt he could trust to follow his lead and anticipate his will. These advisors included not only the political appointees who ran ASPE, the Office of the General Counsel ("OGC"), and other highly institutionalized staff agencies, but also a layer of bureaucratically freefloating special assistants, many of them young lawyers. These special assistants carried out special assignments for the Secretary and monitored the staff agencies to ensure that they met deadlines, resisted the influence of the career bureaucrats, and adhered to the paths laid out for them by the Secretary.

Because I worked closely with the Department's lawyers ${ }^{7}$ in this highly competitive bureaucratic environment, but also operated at an explicitly structured organizational and functional distance from them, I was in an unusually favorable position to observe both their strengths and their limitations. To all appearances, DHEW's lawyers-in the General Counsel's office and elsewhere-were talented professionals and effective bureaucrats. As highly educated, legally skilled, technically informed, politically astute, hard working, and conscientious public servants, they performed their jobs very well. As generalists accustomed to integrating the inputs of other, more specialized disciplines, they were well situated to enhance the decision process in a polyglot department that spanned many diverse policy communities with different approaches and concerns. As members of a profession particularly esteemed by their Secretary, the lawyers' influence was even greater than usual. They seemed to be particularly effective when dealing with the traditional materials and methodologies of the law-the drafting and interpretation of statutes and regulations, the litigation of cases, the counseling of line officials, and the reading of judicial

5. In this essay, I use "bureaucrats" simply as a descriptor of officials who operate in a large, hierarchical organization, not as a pejorative.

6. This belief, of course, had ample support not only in his personal political experience but in the more systematic academic studies of bureaucratic politics.

7. The discussion that follows primarily applies to those lawyers who were hired to work qua lawyers (in the Office of the General Counsel but also on in the legal arms of the program offices), not to those lawyers (like me) who were hired to perform other functions. For a study of government lawyers focusing on those in the Department of Justice and in agencies, see DONALD L. HOROWITZ, THE Jurocracy: Government LaWyers, AgenCy Programs, AND Judicial DeCisions (1977). 
tea leaves. It should come as no surprise, then, that in all of this the lawyers' work was exemplary.

On the theory, however, that we can learn more from criticism than from praise (a theory assiduously practiced by my teachers and athletic coaches through the years), I shall devote the remainder of this brief essay to the following claim: Many government lawyers ${ }^{8}$ make a less valuable contribution to the policymaking process than their natural talents, acquired skills, industry, and prominence in public life would lead us to hope and expect. This claim, I hasten to add, rests on personal impressions gained during my experience at DHEW, not on any systematic evidence. Nevertheless, I strongly suspect that this deficiency does apply to government lawyers generally.

The problem, I believe, has nothing to do with anything peculiar to lawyers in one or another agency. Instead, the main culprit is legal education itself. The narrowness of the curriculum at most law schools deprives students of the full complement of skills, information, and sensitivities that they will need when they later enter public service as government lawyers and policymakers. In particular, law schools fail to provide a sophisticated understanding of the nature and practice of policy analysis and evaluation, the problems of policy implementation, and the diversity and complexity of the political and social institutions (including markets) that constitute and constrain the policy environment.

The processes through which government agencies develop their policies are exceedingly complex. Formal procedures, informal politics, legal interpretation, the force of inertia, and pure happenstance all play important parts. In addition, the practice of policy analysis - the more or less systematic consideration and evaluation of alternative courses of action in terms of the expected magnitude, type, and distribution of their benefits and costs (very broadly defined)-is often a crucial activity. This is true even though policy analysis is as much art as science; it also can be (and often is) manipulated to reach results desired on other grounds, and it seldom will be decisive in itself. For better or worse (I think better), a growing number of government decisions are subject to requirements, imposed by statute or executive order, that the decisionmakers predict, analyze, and evaluate the significant impacts of their decisions before acting, and that they make those analyses available to the public.

Even in the absence of a legal requirement for such analyses, however, government lawyers considering possible statutory or regulatory provisions should be trained to think systematically and to converse knowledgeably about their

8. In the discussion that follows, I emphasize the importance of policy analytical skills to government lawyers. These skills, however, are equally valuable to private lawyers who represent businesses, nonprofit organizations, or individuals seeking to understand and influence public policy at any level of government. The more accurate, more encompassing category for discussion, then, might be public lawyers or public lawyering. The need of public lawyers for such skills has nothing to do with which side of a policy dispute they happen to represent, but reflects a more fundamental condition: the increasingly technocratic nature of contemporary government.

I am also primarily concerned with the civil side of public law, although much of the discussion applies as well to criminal law. 
potential social impacts-at least insofar as those impacts are not simply black boxes or random events but can be predicted with some degree of accuracy (an important qualification, needless to say). Obviously, any competent lawyer will want to anticipate the range of different fact situations to which the rule in question might apply, if only to anticipate its possible scope. This is the stuff of the standard Socratic method in law school classrooms, and able lawyers presumably know how to do it well.

But where public decisionmakers have some choice among competing rules-which is to say, in the vast majority of situations in which government lawyers find themselves-the lawyer cannot limit herself to predicting how each rule might apply to a stylized set of facts; and even that may be difficult given the ambiguities of language and the diversity of possible fact situations. She must also evaluate the competing rules from some broader normative perspective so that she (or the policymakers whom she advises) can choose among them. In order to do this, she needs to employ some methodologies of policy analysis and of choice (for example, cost-benefit or cost-effectiveness analysis), or at least to understand and be familiar with the methodologies employed by the policymakers for whom she works. Finally, she must be able to converse knowledgably with others in the policy environment-legislative liaisons in the agency, program managers, congressional staff, OMB staff, interest group members, and the like - who often speak the language (or jargon) of policy analysis, which of course includes a good deal of economics. This language, after all, is increasingly part of the lingua franca in which technocrats conduct their discourses both in and outside of government.

I hasten to add three points by way of clarification. First, I mean to define policy analysis broadly. In this sense, it refers to any relatively systematic, rigorous effort to identify the alternative courses of action that may be open to policymakers and to anticipate and evaluate their direct and indirect consequences. Thus, policy analysis encompasses more than the familiar economic techniques like cost-benefit and cost-effectiveness analysis; it also includes "softer" ways of thinking about the social and historical factors that shape government programs and frame the environment of policy choice. Second, it should go without saying (but I wish to say it anyway) that policy analytical skills are not the only, or even the most important, skills that government lawyers need in order to maximize their effectiveness. A partial list of other essential skills would include flexibility and a talent for compromise, time management, consensus building, leadership, personnel management and development, negotiation, communications, media and public relations, tolerance of other viewpoints, physical endurance, sense of humor, willingness to take personal responsibility but to let others take credit, and, of course, political astuteness. I emphasize here the value of understanding policy analysis, policy implementation, and social institutions not because that is the most important skill but

9. Many of these skills were suggested (and exemplified) by Dan Meltzer, a former DHEW collegue, who kindly read an earlier version of this paper. 
because it is one that law schools could teach. Indeed, some already do, but most do not. In contrast, most of the other skills can only be acquired through character or experience on the job. Finally, of course, some government lawyers are no doubt perfectly comfortable with policy analysis.

\section{II}

\section{LAWYERS AND POLICY ANALYSIS}

In my experience at DHEW, most of the lawyers seemed profoundly uncomfortable dealing with policy analysis. Whether they were drafting proposed regulations, considering proposed legislative changes, advising agency clients, writing legal memoranda, or deciding whether and on which grounds to appeal a judicial ruling, they seemed strongly to prefer confining themselves to a more legalistic analysis of statutory authority or of a rule's consistency with earlier judicial decisions. My impression was that they felt that policy analysis simply was not in their job description as government lawyers, a feeling that was reinforced by the quite conventional functional divisions of the departmental structure.

Their precise reasons for retreating to the psychological and professional comforts of legal formalism were never altogether clear to me. Perhaps they found policy analysis too "soft" or subjective or political a task for career officials trained in the law and hired to work as lawyers. They may have concluded that policy analysis was not really "legal" work. Perhaps they felt that they lacked the time to gather the necessary data, or to consider data assembled by others, or even to consult closely with the policy analysts in ASPE who were supposed to be in command of these data. Some, however, surely did accept the notion, which has long been a fundamental tenet of American legal education, that lawyers who are assessing the legality or wisdom of alternative rules should try to think carefully about the policy consequences of those alternatives. They may even have accepted the possibility that their decisionmaking superiors (for example, the General Counsel, the Secretary, or the program head) wanted and expected them to include such considerations in their overall analysis. Even so, they might have felt that they were poorly equipped to undertake such an effort and that it was better left to others who had been trained, and were expected, to do it.

Each of these reactions is perfectly sensible, intelligible, and even predictable. All technically-trained professionals feel most competent when they are working within the familiar methodologies and operating routines that mark their profession and distinguish it from others. They resist being drawn across disciplinary boundaries, especially when they are not rewarded either for the effort required or for the increased risk of being wrong (or at least criticized). We should not expect government lawyers to be any different than other narrowly-trained professionals in this respect. Indeed, government lawyers, who are often in their first job out of law school, may tend to take an even narrower view of their professional task than other lawyers who may have had the expe- 
rience, and enjoyed the luxury, of analyzing problems more broadly for private clients who were proposing or resisting government rules.

But this, of course, only raises the further question: Why do we train lawyers so narrowly? Why do they graduate from law school perfectly capable of parsing caselaw, interpreting statutes, and synthesizing other legal materials in order to analyze what the law does and does not permit, but feeling out of their element in analyzing whether the law is desirable, how it is likely to work in the real world, and whether a better law could be devised for the purpose?

This legal parochialism may seem functional; after all, specialization of function is often the most efficient way to organize productive activity. In the highly competitive policymaking process, however, it is highly problematic. If government lawyers do what comes naturally and operate merely as skillful legal technicians, they will marginalize themselves. In order to be fully effective, they must also become policy adepts in the domains in which they specialize. After all, the policymakers whom they advise (and whom they may eventually hope to become) are obliged to exercise broad policy discretion day in and day out. Policymakers do not-and if they are wise, should not-compartmentalize their complex decisions into bureaucratically- or professionally-defined categories such as "legal," "policy," "technical," and "political." In their minds, and in reality, these and many other decision elements are inextricably linked. Accordingly, policymakers will prefer to seek sophisticated analysis and advice from individuals with a more comprehensive, instrumental, integrated view of the relevant choices.

Two examples from my DHEW experience may help to illustrate my point. The first concerns Section 504 of the Rehabilitation Act, ${ }^{10}$ which prohibits discrimination on the basis of disability in federally-assisted programs and activities. Section 504 required the Department to develop the government-wide regulations needed to implement that prohibition. Secretary Califano did not want to lodge this regulatory responsibility in the DHEW officials who administered programs for the disabled, presumably because he feared that they would be overly responsive to the organizations that advocated disability rights and had formed close political alliances with those program officials. Nor did he want ASPE to be the lead agency, probably because it was already overburdened with the rapid development of proposals for welfare reform, national health insurance, child health, Social Security reform, and other major policy initiatives high on the White House's agenda. Instead, Califano turned to his trusted, talented OGC lawyers, delegating to them the responsibility to prepare the regulations, with the assistance of ASPE and the other agencies in the Department and with some consulting from agencies of other affected departments.

This was a formidable task, and the legal aspects were the least of it--or so it seemed to me. But this, of course, is precisely my point. As is often the case,

10. Pub. L. No. 99-506, tit. V $\$ 504,87$ Stat. 394 (1973) (codified at 29 U.S.C. $\S 794$ (1994)). 
Congress had formulated Section 504 with little focused attention and in the most general terms, leaving the regulators with broad policy discretion within which almost any reasonable regulation was likely to pass judicial muster. In determining regulatory authority, after all, a court would likely defer to the Department's policy purposes and behavioral predictions. But while the OGC lawyers did not have to concern themselves overmuch with the legal risks of the regulations, they found the political aspects of Section 504 extraordinarily delicate and challenging. The disability rights advocates were well-organized and highly effective, with staunch allies in key positions in Congress and the media, and with much support in public opinion. Early in the regulatory process at DHEW, their organizations had thrown up picket lines around Califano's home, a tactic that infuriated the proud, liberal Secretary; it was a humiliating experience that he was determined not to repeat.

The policy issues were even more daunting than the politics. Congress had enacted Section 504 almost as an afterthought, without having conducted any significant empirical studies. ${ }^{11}$ The new law promised to create many tangible and intangible benefits for the disabled and for American society generally, but until specific regulations were issued, implemented, and applied in real-world settings, these benefits could not really be measured or meaningfully estimated. Even more elusive were the magnitude of the costs that the regulations would impose, and the distribution of those costs among taxpayers, communities, and institutions. Adding to these uncertainties was the fact that these regulations were to be government-wide, creating a model to which each specific set of federal agency regulations must conform. Therefore, the lawyers were obliged to develop the DHEW regulations with a view toward their application to a vast number of diverse programs conducted in almost infinitely varied settings.

The second example arose in connection with the Department's obligation to develop an implementation plan for complying with a court order in Adams v. Califano, ${ }^{12}$ a private action brought against DHEW under Title VI of the Civil Rights Act of 1964. The plaintiffs had persuaded the district judge that DHEW had violated Title VI by distributing federal funds to public institutions of higher education in the southern and border states despite the fact that those states had continued to maintain dual systems of public higher education segregated by race. Within DHEW, the Office of Civil Rights ("OCR") had the primary responsibility for developing and enforcing the standards and procedures according to which the states' (and hence DHEW's) compliance with Title VI would be appraised, but the Secretary instructed OCR to fashion its standards in close consultation with education policy experts in ASPE and in the relevant education program agencies in the Department, as well as with OGC and other staff agencies. OCR was headed by David Tatel, an outstand-

11. For an insightful discussion of the history of Section 504 as applied to transportation policy, see Robert A. KATZMANN, Insitutional DisAbility: The SAGA OF TRANSPORTATION POLICY FOR THE DISABLED (1986).

12. 430 F. Supp. 118 (D.D.C. 1977). 
ing civil rights lawyer who is now a judge on the D.C. Circuit. Not surprisingly, Tatel and his staff were determined to meet the letter of the court's order, which if violated could result in contempt proceedings against the Department. The educational policymakers, however, had a number of different considerations in mind as well.

The most delicate of these concerned the likely fate under a desegregation plan of the black land-grant colleges and other institutions that for over a century had trained virtually all of the black college students receiving public higher education in those states. Operating under the most difficult (and illegal) political and fiscal constraints, these institutions-virtually all of whose students, faculty, and administrators were black-had somehow managed to train generations of often ill-prepared, low-income students. Indeed, these institutions had educated much of the black middle class in those (and other) states. Although the Department was under immense legal pressure from the court to dismantle the dual system and create a single, integrated one, the education policy specialists feared that doing so would essentially eliminate the black institutions by folding their best programs into the larger, more urban, better funded, and more politically influential traditionally white institutions in each region, or by closing them down altogether.

Attuned to the distinctive character of the market for higher education, particularly among black aspirants in those states, the policy specialists predicted that a significant share of the young blacks who could not afford to matriculate outside the state would much rather attend the traditionally black schools in their region than the white institutions. They pointed out that many of the black students who had received inferior primary and secondary educations in de facto segregated schools would be denied admission to the white schools and might be left with no institution to attend within traveling distance of their homes. Others preferred to be educated by predominantly black faculty who were deeply committed to the intellectual and economic progress of their students. Many also feared that they would be ignored or mistreated or feel alienated in institutions that, even after integration, would remain overwhelmingly white. The education policy specialists also argued that many of the black professionals associated with the traditionally black institutions, who constituted much of the black leadership in those communities, would lose their jobs or would have to accept inferior status in the surviving, predominantly white institutions where they would often be competing with more highly credentialed individuals.

The lawyers in OCR and OGC were not wholly insensitive to these arguments, of course, but they had difficulty in dealing with them on their policy merits and in thinking about possible alternative approaches that were consistent with the educational values of these institutions and with the way in which this particular education market worked. Indeed, they resisted seeing it as a market at all, and because of this they were not as well equipped as they might have been to predict the behavioral responses of particular requirements under consideration. Still less did they appreciate the policy implications of the fact 
that in the higher education market, students could choose which institutions they would attend and did so on the basis of their location, curricular goals, financial resources, transportation needs, racial sensibilities, and other factors. Instead, the lawyers seemed to cling for security to the traditional civil rights scenario, in which the court could compel the desegregation of elementary and secondary education by assigning students to specific schools in order to achieve some judicially-determined racial balance. When the educational policy specialists pointed this out to them, they recurred, almost reflexively, to the court order as their argumentative weapon, even though the court order provided little guidance as to what, within the requisite legal parameters, would best serve the students, institutions, and other relevant interests.

My point is certainly not that the lawyers were wrong and that the educational policy people were right. The question of how to desegregate the dual system of higher education was-and remains today - a devilishly complex and agonizing problem for which there are no entirely satisfactory solutions, and certainly none that will not make some interests worse off. Equally obvious, the Department, at a minimum, had to comply with the court order. My point, rather, is that the lawyers did not contribute as much to the collaborative process of devising a workable solution to this dilemma as they might have had they been more conversant with the techniques of policy analysis and the policy literature on how higher education markets operated, especially in the South. It seemed to me that they exhibited a kind of rigidity that I now attribute, perhaps mistakenly, to what I earlier referred to as the comforts of legal formalism. This rigidity is the very antithesis of what a government lawyer ought to bring to the challenging task of policymaking in a decision environment that, while legally, institutionally, and politically constrained, nevertheless usually confers considerable policy discretion.

III

\section{CONCLUSION}

As these examples suggest, policy analysis is hardly a straightforward activity that any good lawyer can easily master and competently perform. Quite the contrary. For policy analysis to assist decisionmakers, its practitioners must synthesize a great deal of specialized information and make sound empirical and normative judgments. The analyst must know how to gather, integrate, and interpret data about the social effects of policy-relevant behaviors and about how different types of social influences can shape those behaviors. In order to do this, she must read the specialized social science literature (such as it is) pertaining to the particular policy domain in question, for these empirical relationships are likely to be domain-specific. She must also understand the techniques for converting policy alternatives into common metrics that facilitate comparison and choice. She must be able to identify the normative assumptions that often lie concealed in policy proposals and to bring them to the surface where they can be examined and contested. She must be alert to the 
political, institutional, legal, and other factors that frame policy debates, factors that may impede the implementation of otherwise attractive remedies. She must comprehend how economic markets and social norms work and must be attentive to the complex ways in which these mechanisms interact with, and often confound, governmental interventions. She must be prepared to suggest different ways of accomplishing the policy objectives and, drawing on various policy literatures, to analyze the advantages and disadvantages of each.

Needless to say, this is a very tall order: These skills do not come naturally or easily, and no mortal (much less a humble lawyer) is likely to possess them all. It is also true, however, that most of what passes for policy analysis in the government is conducted by people who do not possess an advanced degree from the Kennedy School or some other public policy program. The skills necessary to enter the policy conversation can only be gained through assiduous study and refined through practice. More to the present point, they can be taught in law schools, along with the more traditional techniques of conventional legal analysis. Law school curricula vary from institution to institution, but I venture that few law schools offer courses in policy analysis and related topics-although some policy-oriented public law courses (such as banking regulation, food and drug law, health care law, or education law) may touch on such topics.

Unfortunately, such courses are most likely to be taught in the elite schools, which can better afford to augment their core curricula. Law students with an interest in public policy analysis may have to look for these courses in the political science department or graduate program in public policy of their university. Even for law schools whose students enjoy easy access to such programs, this is hardly the best way to integrate the subject into legal education. Formal joint degree programs in law and public policy are all well and good, but in practice relatively few of the law students with an interest in public lawyering will be prepared to enroll in such programs.

As the problems of government lawyering go, this should be a relatively easy one to remedy. The law schools-or at least those that can afford it-can draw upon three decades of public policy school experience, experience which of course must be tailored to legal education's distinctive requirements. The most straightforward approach might be for reform-minded law schools to construct a "public lawyering" module (or more grandly, a program) which would augment the many courses in constitutional law, administrative law, and specialized areas of public law (such as environmental law, telecommunications law, and criminal law) that already populate the curriculum. The new module might consist of a cluster of offerings-academic courses, practice-oriented workshops and clinics, and externships in public law organizations-in which the central elements are the analysis, research, evaluation, and implementation of public policies. These offerings would require students to become conversant with quantitative analysis, public choice theory, decision theory, political analysis, the legal, ethical, and philosophical principles that frame the public policymaking process, and other such subjects. 
Would DHEW lawyers trained in this way have been better prepared to grapple with the kinds of questions that they faced in developing the Section 504 regulations and implementing the court order in Adams v. Califano? And would the rules and plans that they would have developed have produced better anti-discrimination policy? It is impossible to know, of course, but I suspect that the answer to both questions is "yes." I am even more certain that the lawyers' influence on the policymaking process would have been (even) greater than it was had they possessed those skills in addition to their legal abilities. What is beyond dispute, however, is that governments at all levels and on all subjects are under increased pressure to organize public institutions more technocratically, to allocate public resources more efficiently, and to justify their decisions more openly, objectively, and convincingly to a more attentive, demanding, and skeptical public. If past is prologue, lawyers will continue to be at the center of these processes and will have to respond to those pressures. They will need all the help that they can get. 